\title{
Peningkatan Pendapatan Petani Melalui Diversifikasi Dan Intensifikasi Tanaman Hortikultura Di Lahan Kering Desa Gumantar Kabupaten Lombok Utara
}

\author{
Jayaputra*, Nurrachman, Bambang Budi Santoso \\ Jurusan Budidaya Pertanian Fakultas Pertanian, Universitas Mataram, Mataram, Indonesia
}

\section{Article history}

Received: 09-02-2021

Revised: 29-02-2021

Accepted: 11-03-2021

*Corresponding Author: Jayaputra,

Jurusan Budidaya Pertanian, Fakultas Pertanian, Universitas Mataram, Mataram, Indonesia;

Email:

jaya_putra@unram.ac.id
Abstract: Planting diversification with horticultural crops in the dry land area of North Lombok Regency is an effort to increase the planting index (IP) which is supported by appropriate cultivation technology and sufficient water availability to support plant growth. It was hoped that the increase in the cropping index in dry land areas will trigger an increase in community welfare, particularly an increase in farmers' income. Horticultural development is intended to provide added value to increasing farmers' income. Gumantar Village, Kayangan District, North Lombok Regency is one of the areas that has dry land which is quite potential for horticultural development. The problems faced by farmers in these areas include the low level of knowledge and skills of farmers, especially in the management of horticultural commodities. So far, farming activities were still traditional and the level of farmer participation was still relatively low. To overcome these problems, it was necessary to transfer innovation technology through the development of environmentally friendly horticultural crops with the application of Good Agricultural Practices and production management in accordance with natural resource conditions. Counseling and training as well as demonstration plots using the Participatory Action Research method related to horticultural cultivation technology have been carried out in Amor-Amor hamlet, Gumantar village in JulyDecember 2019. This community service activity is considered quite successful as seen from the enthusiasm and persistence of the participants in attended counseling, training, and demonstration plots (cultivation of tomatoes and golden melons). The results of the demonstration plot showed a significant increase both in the aspect of crop productivity and increased income per unit area of arable land. Continuous assistance from all parties, especially the local government was highly expected for the sustainability of horticultural commodity development efforts in order to increase the income of dry land farmers.

Keywords: cultivation; demonstration plot; Skills; counseling; productivity

Abtrak: Diversifikasi pertanaman dengan tanaman hortikultura di kawasan lahan kering Kabupaten Lombok Utara merupakan salah satu upaya meningkatkan Indeks Pertanaman (IP) yang didukung oleh teknologi budidaya yang tepat dan ketersediaan air yang cukup untuk mendukung pertumbuhan tanaman. Meningkatnya Indeks Pertanaman di kawasan lahan kering tersebut diharapkan akan memicu peningkatan kesejahteraan masyarakat, khususnya peningkatan pendapatan petani. Pengembangan hortikultura dimaksudkan untuk memberikan nilai tambah terhadap peningkatan pendapatan petani. Desa Gumantar, Kecamatan Kayangan, Kabupaten Lombok Utara merupakan salah satu daerah yang memiliki lahan kering cukup potensial untuk pengembangan hortikultura. Permasalahan yang 
dihadapi petani di daerah tersebut antara lain tingkat pengetahuan dan keterampilan petani terutama dalam pengelolaan komoditas hortikultura yang masih rendah. Selama ini kegiatan usaha tani masih tradisional dan tingkat partisipasi petani relatif masih rendah. Untuk mengatasi permasalahan tersebut, diperlukan transfer teknologi inovasi melalui pengembangan tanaman hortikultura yang ramah lingkungan dengan penerapan Budidaya Pertanian yang Baik (Good Agricultural Practices) dan manajemen produksi yang sesuai dengan kondisi sumberdaya alam. Penyuluhan dan pelatihan serta demplot menggunakan metode kaji terap partisipatif (Participatory Action Reseach) terkait teknologi budidaya tanaman hortikultura telah dilaksanakan di dusun Amor-Amor desa Gumantar pada Juli-Desember 2019. Kegiatan pengabdian kepada masyarakat ini dinilai cukup berhasil dilihat dari antusiasme dan ketekunan peserta dalam mengikuti penyuluhan, pelatihan, dan demplot (budidaya tomat, dan golden melon). Hasil demplot menunjukan peningkatan yang nyata baik pada aspek produktivitas tanaman maupun peningkatan pendapatan per satuan luas lahan garapan. Pendampingan yang berkelanjutan dari semua pihak terutama pemerintah setempat sangat diharapkan untuk keberlanjutan usaha pengembangan komoditas hortikultura guna meningkatkan pendapatan petani lahan kering.

Kata Kunci: budidaya; demplot; keterampilan; penyuluhan; produktivitas

\section{PENDAHULUAN}

Kawasan lahan kering sebagai salah satu sumberdaya pertanian di wilayah Kabupaten Lombok Utara menempati proporsi luas terbesar yakni mencapai 47.653 ha atau sebesar 75,7 persen, sedangkan lahan sawah hanya sebesar 11,8 persen (BPS, 2019). Pola penggunaan lahan sebagian besar pada proporsi lahan kering ini mengandung tantangan yang cukup besar dalam pengelolaannya agar dapat menghasilkan produktivitas yang optimal dalam upaya meningkatkan kesejahteraan masyarakat. Sementara di sisi lain, arah pembangunan pertanian di era reformasi saat ini, antara lain diarahkan kepada pembangunan pertanian yang berorientasi agribisnis, berwawasan lingkungan, dan mampu menunjang upaya pengentasan kemiskinan dan peningkatan kualitas sumberdaya manusia dan mendukung berkembangnya sektor pariwisata. Dalam kaitan dengan itu, maka pengembangan potensi sumberdaya alam khususnya kawasan/wilayah lahan kering untuk pembangunan pertanian mempunyai nilai strategis.

Lahan usahatani yang merupakan lahan kering tersebut dengan kendala utama keterbatasan air, umumnya hanya dapat diusahakan satu kali dalam setahun yaitu pada musim penghujan, dan pada musim kemarau hanya di beberapa titik lokasi kegiatan budidaya dapat dilakukan dengan memanfaatkan sumur bor sebagai sumber air pengairan. Meskipun terdapat sumur bor di beberapa titik lokasi, masyarakat miskin (petani) belum dapat memanfaatkannya secara optimal karena keterbatasan modal usahatani dan menganggap penggunaan sumur bor sebagai sumber air pengairan usahatani sangat membebani biaya produksi tidak sebanding dengan hasil yang diperoleh. Jenis tanaman yang diusahakan juga sangat terbatas, seperti padi, tanaman jagung, kacang hijau dan kacang tanah serta beberapa jenis tanaman hortikultura seperti sayuran: tomat, cabai, dan kacang panjang. Pola penanaman dengan jenis komoditas tersebut, terutama tanaman hortikultura tidak mengalami pengembangan karena pengetahuan dan keterampilan petani yang masih sangat terbatas mengenai teknologi budidaya berbagai komoditas hortikultura yang lebih prospek menguntungkan untuk 
diusahakan di lahan usaha taninya (lahan kering) sesuai dengan daya dukung lingkungan/ ketersediaan sumberdaya setempat.

Selama ini kegiatan budidaya tanaman di Kabupaten Lombok Utara khususnya di Desa Gumantar, umumnya masih bersifat tradisional menurut kebiasaan yang sudah turun temurun dengan ketergantungan yang sangat tinggi dalam penggunaan pupuk dan pestisida kimia untuk menunjang pertumbuhan dan hasil tanamannya. Dengan semakin mahalnya saprodi pertanian terutama pupuk dan pestisida kimiawi, maka biaya produksi dalam budidaya tanaman akan semakin tinggi dan kondisi ini tentu dirasakan sangat berat bagi petani dalam menyediakan modal awal usahatani terutama bagi masyarakat miskin (petani). Demikian juga teknik budidaya, sistem tanam maupun dari segi pemilihan tanaman yang diusahakan serta pola pengusahaannya tidak intensif dan belum berorientasi pasar, khususnya tanaman hortikultura yang sangat potensial yang dapat dikembangkan sesuai daya dukung lahan dan iklim yang menunjang. Dengan kondisi keterbatasan/ kendala lahan pertanian (lahan kering) serta pengelolaan budidaya tanaman yang masih bersifat tradisional tersebut, produktivitas tanaman yang diusahakan sangat rendah di bawah produktivitas rata-rata. Hal ini tentu akan berdampak terhadap rendahnya pendapatan petani. Di sisi lain, dengan penggunaan pupuk dan pestisida kimia yang sangat intensif tentu akan berdampak terhadap pencemaran lingkungan.

Diversifikasi tanaman dengan tanaman hortikultura di kawasan/wilayah lahan kering Kabupaten Lombok Utara merupakan salah satu upaya untuk meningkatkan Indeks Pertanaman (IP) yang didukung oleh teknologi budidaya yang tepat dan ketersediaan air yang cukup untuk mendukung pertumbuhan tanaman. Meningkatnya Indeks Pertanaman di lahan kering diharapkan akan memicu peningkatan kesejahteraan masyarakat, khususnya peningkatan pendapatan petani.

Pengembangan tanaman hortikultura di lahan kering, selain ditujukan untuk meningkatkan indeks pertanaman (IP), berhubungan juga dengan isu pembangunan pertanian secara umum, seperti permasalahan dalam usaha untuk meningkatkan produksi, mutu dan daya saing produk hortikultura, serta hubungannya dengan penerapan budidaya pertanian yang baik, penataan rantai pemasaran dan kelembagaan petani. Pengembangan hortikultura dimaksudkan untuk memberikan nilai tambah terhadap peningkatan pendapatan petani. Isu pembangunan pertanian tersebut khususnya bidang hortikultura memerlukan pendekatan secara menyeluruh yang melibatkan berbagai lintas disiplin ilmu.

Desa Gumantar kecamatan Kayangan kabupaten Lombok Utara merupakan salah satu daerah yang memiliki lahan kering yang cukup potensial untuk pengembangan hortikultura. Permasalahan yang dihadapi oleh petani lahan kering di daerah tersebut antara lain tingkat pengetahuan dan keterampilan petani terutama dalam pengelolaan komoditas hortikultura yang masih rendah. Selama ini kegiatan usaha tani masih tradisional dan tingkat partisipasi petani yang relatif masih rendah. Untuk mengatasi permasalahan tersebut, diperlukan transfer teknologi inovasi melalui pengembangan tanaman hortikultura yang ramah lingkungan dengan penerapan Budidaya Pertanian yang Baik (Good Agricultural Practices) dan manajemen produksi yang sesuai dengan kondisi sumberdaya alam.

Hasil beberapa kegiatan penelitian (kaji tindak) yang telah dilakukan menunjukkan bahwa pengembangan tanaman hortikultura yang benilai ekonomi tinggi seperti Tomat, Cabai, Melon, Bawang merah, kacang panjang dan tanaman hortikultura lainnya sangat cocok dengan kondisi lingkungan agroklimat setempat dengan penerapan teknologi budidaya yang baik dan inovasi pemanfaatan air yang efisien dari sumber air pengairan sumur bor (Sauqi at al., 2017, Zainuri at al., 2017).

Berdasarkan uraian di atas, maka telah dilakukan kegiatan pengabdian kepada masyarakat untuk meningkatkan pengetahuan dan keterampilan masyarakat petani di desa Gumantar dalam 
mengelola sumberdaya lahan lahan kering melalui intensifikasi dan divesifikasi tanaman dengan budidaya tanaman hortikultura guna peningkatan pendapatan petani. Program pengabdian kepada masyarakat ini dilaksanakan sejak bulan Juli sampai dengan bulan Desember 2019, bertujuan untuk 1) Melakukan transfer teknologi melalui kegiatan penyuluhan, pelatihan/ demplot, dan pendampingan kepada masyarakat petani lahan kering untuk meningkatkan pengetahuan dan keterampilan dalam rangka mengembangkan komoditi-komoditi hortikultura unggulan dan komoditi pendukung serta mendorong tumbuh kembangnya usaha agribisnis hortikultura di desa Gumantar yang berakar pada kemampuan sumberdaya lokal yang ada; 2) Meningkatkan kapasitas petani dan kelompok tani melalui bimbingan teknis dalam pengembangan lahan kering yang berkelanjutan dengan komoditas hortikultura sebagai komoditi andalan; dan 3) Meningkatkan status ekonomi masyarakat dengan mengembangkan potensi daerah melalui kegiatan transfer teknologi yang berkelanjutan.

\section{METODE}

Kegiatan pengabdian kepada masyarakat ini dilaksanakan Dusun Amor-Amor Desa Gumantar Kecamatan Kayangan Kabupaten Lombok Utara. Peserta kegiatan adalah anggota kelompok Tani Lembah Telaga sebanyak 20 orang petani yang terdiri dari petani yang sudah pernah melakukan budidaya komoditas hortikultura dan petani yang belum pernah melakukan budidaya komoditas hortikultura. Penentuan petani binaan ini dilakukan oleh ketua dan sekretaris kelompok tani lembah telaga dan Tim PPM Fakultas Pertanian Universitas Mataram. Petani binaan yang dipilih adalah petani yang mempunyai motivasi untuk mengikuti kegiatan pengembangan lahan kering dengan budidaya tanaman hortikultura sebagai komoditi andalan.

Kegiatan pengabdian kepada masyarakat ini diawali dengan melakukan sosialisasi dan pengumpulan data dengan menggunakan metode observasi. Pelaksanaan kegiatan menggunakan metode pendekatan sosial yang menempatkan masyarakat binaan sebagai subyek kegiatan dan metode kaji terap partisipatif (Participatory Action Reseach) pada tahap pelatihan kelompok tani binaan, dan praktik demonstrasi plot (demplot) untuk percepatan alih teknologi dan pembinaan langsung oleh tim pelaksana.

Pemberdayaan masyarakat dengan metode ini pada dasarnya adalah upaya pelibatan masyarakat untuk belajar dan beraktivitas secara berkelanjutan dalam rangka meningkatkan kualitas hidup mereka. Oleh karena itu, dalam kegiatan pengembangan dan budidaya tanaman hortikultura di lahan kering yang berkelanjutan, masyarakat dilibatkan dalam setiap tahapan kegiatan, mulai kegiatan perencanaan, pelaksanaan, pemanfaatan hasil kegiatan dan evaluasi terhadap pelaksanaan program. Dengan cara seperti ini, maka diharapkan kegiatan kaji terap partisipatif dalam pengembangan dan budidaya tanaman hortukultura di lahan kering yang tersusun adalah program kegiatan yang sesuai dengan kebutuhan masyarakat.

Kegiatan Penyuluhan dilaksanakan dengan cara ceramah disertai dengan presentasi menggunakan Power Point dan dikuti diskusi/ tanya jawab. Presentasi Power Point dimaksudkan untuk mempertegas maksud dari ceramah dan meberikan contoh-contoh teknik pengelolaan/ budidaya tanaman hortikultura dengan menampilkan secara visual penerapan berbagai teknologi budidaya tanaman hortikultura bernilai ekonomi tinggi yang dapat dijadikan sebagai komoditas andalan.

Selain dilakukan ceramah dan diskusi, kegiatan dilanjutkan dengan pelatihan/ demplot budidaya beberapa tanaman hortikultura yang memiliki nilai ekonomi dan disesuaikan dengan kebutuhan masyarakat setempat dan pasar serta penerapan teknologi budidaya ramah lingkungan yang 
ditawarkan, di antaranya teknik pemanfaatan limbah rumahtangga, sisa-sisa tanaman, kotoran ternak untuk pembuatan kompos dan pengenalan tanaman lokal setempat yang potensi untuk pestisida hayati.

Untuk melakukan bimbingan secara intensif pada setiap kegiatan yang dilakukan oleh petani mitra binaan, maka dilakukan pendampingan di lapangan. Tim PPM Fakultas Pertanian Universitas Mataram berperan sebagai tenaga ahli yang melakukan transfer pengetahuan dan teknologi di lapangan yang dilakukan secara berkala sesuai dengan kebutuhan dan kendala yang dihadapi petani binaan di lapangan.

Evaluasi merupakan kegiatan akhir program pengabdian kepada masyarakat yang dilakukan terhadap peran dan keterlibatan peserta, antusiasme serta serapan peserta terhadap kegiatan penyuluhan, demplot dan bimbingan yang telah dilakukan.

\section{HASIL DAN PEMBAHASAN}

Sesuai dengan tujuan yang telah ditetapkan dan metode pelaksanaan kegiatan, pelaksanaan program pengabdian kepada masyarakat ini dilaksanakan dengan tahapan sebagai berikut:

\section{Tahap persiapan}

Tahap persiapan dimulai sejak bulan Juli 2020 sampai menjelang pelaksanaan kegiatan penyuluhan dan pelatihan/demplot. Pada tahap ini, telah dilakukan pendekatan-pendekatan dengan berbagai unsur dalam masyarakat seperti tokoh masyarakat, tokoh agama, tokoh pemuda, kelompok tani dan pemerintahan desa. Beberapa hal yang dilakukan pada tahap persiapan meliputi:

a. Observasi dan Sosialisasi program kegiatan kepada masyarakat. Kegiatan ini dilakukan untuk mengidentifikasi potensi wilayah lokasi kegiatan dan penyamaan persepsi dengan berbagai unsur dalam masyarakat seperti tokoh masyarakat, tokoh agama, tokoh pemuda dan pemerintahan desa. Penyamaan persepsi ini berkaitan dengan potensi sumberdaya manusia dan potensi sumberdaya alam yang bisa dan akan dikembangkan, kondisi sosial ekonomi, budaya, kondisi ketersediaan air, pola pemanfaatan lahan kering, penerapan teknologi anjuran atau teknologi budidaya yang sudah dilaksanakan oleh masyarakat, peluang pasar dan jaringan pemasaran hasil pertanian, SDM, pengetahuan, keterampilan dan sarana prasarana pendukung lainnya.

b. Penetapan petani yang menjadi mitra binaan sasaran program kegiatan pengabdian kepada masyarakat. Petani yang dipilih adalah petani yang mempunyai motivasi untuk mengikuti kegiatan pengembangan lahan kering dengan basis pengembangan dan budidaya komoditas hortikultura sebagai komoditi andalan dan memiliki kemauan untuk memperbaiki produktivitas lahan pertaniannya. Penentuan petani binaan ini dilakukan oleh ketua kelompok tani sesuai saran dan persyaratan yang telah ditetentukan oleh Tim Pelaksana.

c. Penetapan waktu pelaksanaan kegiatan penyuluhan dan pelatihan/ demplot pengembangan dan budidaya tanaman hortikultura dengan penerapan teknologi budidaya hortikultura sesuai dengan kondisi setempat. Pelaksanaan disepakati dilakukan bulan Agustus 2020.

d. Diskusi Tim Pelaksana untuk solusi masalah, hambatan dan kendala dalam pelaksanaan program kegiatan.

e. Persiapan/pengadaan bahan dan alat untuk kegiatan penyuluhan dan demplot. 


\section{Tahap Pelaksanaan}

Tahap pelaksanaan meliputi kegiatan Penyuluhan, Pelatihan/ Demplot dan Pendampingan. Kegiatan penyuluhan dilakukan dengan menyampaikan materi secara langsung oleh Tim PPM yang diikuti diskusi/ tanya jawab terhadap materi yang disampaikan dan permasalahan yang dialami masyarakat sasaran dalam budidaya dan pengembangan tanaman hortikultura. Penyampaian materi penyuluhan dilakukan melalui media dalam bentuk powerpoint yang ditanyangkan melalui LCD proyektor. Kegiatan pelatihan/ demplot diawali dengan pembuatan kompos dengan memanfaatkan limbah rumah tangga, sisa-sisa tanaman, kotoran ternak dan pengenalan tanaman lokal setempat yang berpotensi untuk dijadikan pestisida hayati yang dilakukan berselang 1 (satu) minggu berikutnya setelah kegiatan penyuluhan sesuai kesepakatan dan untuk mempersiapkan bahan-bahan dan alat yang diperlukan untuk kegiatan demonstrasi. Sedangkan demplot penerapan teknologi budidaya hortikultura beberapa tanaman hortikultura di lahan demplot dilaksanakan 14 hari kemudian setelah kegiatan demplot pembuatan kompos, sambil menunggu kesiapan lahan (pengolahan tanah dan pembuatan bedengan) dan bibit semaian siap pindah tanam.

Sasaran pelatihan/ demonstrasi pembuatan pupuk organik adalah untuk digunakan sebagai bahan pemupukan tanaman hortikultura yang diusahakan. Sedangkan demplot budidaya tanaman hortikultura dan pengembangannya di lahan sawah maupun di polibag sebagai tanaman untuk mengisi lahan pekarangan ditujukan sebagai salah satu alternatif komoditi yang dapat dikembangkan untuk meningkatkan pendapatan dan memenuhi kebutuhan sehari-hari.

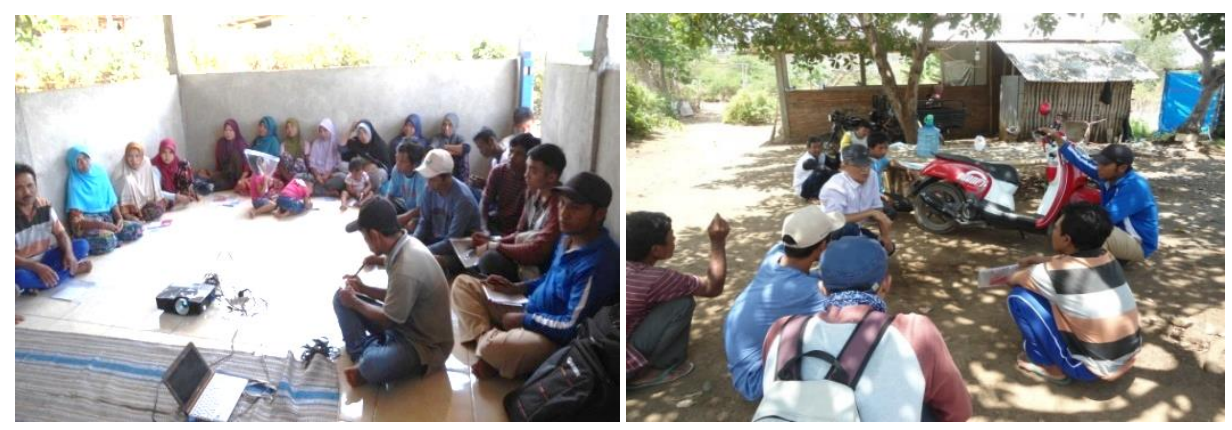

Gambar 1. Suasana kegiatan Penyuluhan dan pelatihan

Pelatihan/ demonstrasi dilakukan dengan memberikan petunjuk dan praktek langsung dalam hal teknik pembuatan pupuk organik dan teknik budidaya tanaman hortikultura di lahan sawah maupun di lahan pekarangan menggunakan polibag, dimulai dari persiapan bahan dan alat, pencampuran media untuk kompos, persemaian, persiapan lahan, pengisian polibag dengan media tanam (untuk budidaya di pekarangan), penanaman, sistem penanaman, dan pemeliharaan tanaman. Bahan dan alat untuk keperluan demonstrasi telah dipersiapkan sebelumnya oleh TIM pengabdian kepada masyarakat, seperti: starter untuk pengomposan (EM-4 dan stardec), benih sayuran tomat, golden melon (buah semusim), terong, sawi, selada, dan benih lainnya, polibag, mulsa plastik, hand sprayer, kompos, pupuk dan pestisida organik. Sementara alat dan bahan lainnya disiapkan masyarakat peserta seperti lahan demplot, cangkul, media tanah, kotoran ternak bambu dan lain-lain. Demplot teknik budidaya tanaman hortikultura di lahan sawah dilakukan pada luasan lahan kurang lebih 5 Are per komoditi dengan pemilihan tanaman Tomat dan Golden Melon sebagai tanaman demplot dengan populasi tanaman masing-masing sebanyak 1000 pohon. Pemilihan tanaman hortikultura yang dibudidayakan 
di lahan kering lokasi kegiatan didasarkan pada beberapa pertimbangan: Pertama, bahwa tanaman tersebut sesuai untuk topografi dan iklim setempat, sehingga tanaman yang usahakan adalah tanaman dataran rendah, yang mampu beradaptasi dengan temperatur yang cukup tinggi. Kedua, benih atau bibit tanaman mudah diperolah. Hal ini diperlukan apabila tanaman tersebut berhasil dibudidayakan dan akan dikembangkan lebih lanjut oleh masyarakat. Selanjutnya, nilai ekonomi atau harga produk tanaman tersebut cukup tinggi serta mudah dipasarkan.

Hasil dari kegiatan demplot pembuatan kompos diperoleh kompos siap pakai kurang lebih sebanyak 2 kuintal dan siap digunakan sebagai pupuk dasar untuk memperbaiki kondisi/kesuburan tanah. Beberapa petani sudah mulai mencoba melakukan duplikasi kegiatan tersebut secara mandiri. Sedangkan hasil demplot budidaya tomat diperoleh hasil lebih kurang 1,9 ton/1000 tanaman (luas kl 4 are) setara dengan 52,78 ton/Ha. Hasil produksi melon lebih kurang 2,7 ton/ 1000 tanaman (luas kl 5 are) setara dengan 64,58 ton/Ha. Dengan hasil produksi tersebut diperoleh nilai jual tomat sebesar Rp7.600.000 (harga jual Rp.4000/kg) atau pendapatan sebesar Rp. 3.700.000,- (nilai jual dikurangi biaya produksi Rp.3.900.000). Nilai jual golden melon sebesar Rp. 21.600.000,- (harga jual Rp.8000/kg) atau pendapatan sebesar Rp. 15.900.000,- (nilai jual dikurangi biaya produksi Rp.5.700.000). Sementara pendapatan yang bisa diperoleh petani dari usahatani/ budidaya jagung yang umumnya mereka tanam setiap tahun, rata-rata sebesar Rp.9.000.000,- per hektar. Hal ini menunjukkan bahwa produktivitas dan keragaman tanaman hortikultura yang dapat diusahakan di KLU memiliki peluang yang sangat besar untuk dapat ditingkatkan. Lebih lanjut tentunya diperlukan kegiatan yang mengarah pada penguatan kelembagaan kelompok sehingga penanganan kawasan budidaya berbagai jenis tanaman hortikultura dapat dilakukan secara teratur dan berkelanjutan serta dapat memberikan nilai tambah untuk peningkatan ekonomi bersama.

Dengan melihat dan mengamati pertumbuhan dan perkembangan tanaman tomat dan perolehan hasil yang cukup memuaskan dari budidaya tanaman hortikultura tersebut, para petani binaan menjadi sangat tertarik untuk pengembangan lebih lanjut (duplikasi kegiatan demplot), namun mereka terkendala dengan modal awal (usahatani), dan mereka masih sangat mengharapkan pendampingan lebih lanjut. Hal ini menunjukkan bahwa pada dasarnya masyarakat petani sadar dan mau berbuat untuk mengembangkan tanaman hortikultura untuk meningkatkan pendapatannya, asalkan mereka diberikan keyakinan dan pendampingan yang berkelanjutan karena mereka melihat secara langsung hasil nyata dari kegiatan pengabdian ini. Oleh karena itu bimbingan dan pendampingan yang berkelanjutan terutama dari aparat pemerintah desa setempat dan instansi terkait sangat diperlukan.

\section{Kendala-kendala dalam pelaksanaan kegiatan pengambdian dan cara mengatasinya}

Kendala utama dalam budidaya tanaman dilahan kering adalah ketersediaan air untuk pengairan yang terbatas. Dalam budidaya tanaman, terutama tanaman hortikultura, ketersediaan air yang cukup selama proses produksi merupakan faktor utama yang menentukan kuantitas maupun kualitas hasil (keberhasilan usahatani). Masalah keterbatasan air diatasi dengan inovasi membuat bak penampungan air sederhana menggunakan alas penampung dari terpal ukuran 4x6 meter ${ }^{2}$ (daya tampung air lk 5000 liter). Bak penampungan diisi terlebih dahulu pada saat pengairan sistim leb yang dilakukan 2 minggu sekali, sehingga rentang waktu sampai pengairan leb berikutnya, di areal pertanaman masih tersidia air untuk mengairi tanaman bila diperlukan, menggunakan gembor. Dengan cara seperti ini tanaman tidak akan kekurangan air selama pertumbuhannya. Bak penampungan air ini mampu untuk mengatasi kebutuhan air bagi tanaman setelah pengairan leb selama 2 minggu untuk luas areal tanam kurang lebih 10 Are/ 0,1 Ha. Oleh karena itu bak 
penampungan air ini perlu dibuat untuk setiap luasan 10 are areal penanaman. Prinsip pokok dalam pengunaan air dalam budidaya tanaman di lahan kering adalah efektifitas dan efisiensi yang didasarkan pada kebutuhan tanaman budidaya. Oleh karena itu teknik efisiensi penggunaan air ini hanya akan efektif bila petani memahami karakteristik tanaman (relatif berbeda antar jenis tanaman yang satu dengan tanaman yang lainnya) kaitannya dengan ketersediaan serta pemenuhan kebutuhan air pada setiap fase pertumbuhan dan perkembangan tanaman.

Pengetahuan dan penguasaan teknologi budidaya tanaman yang masih rendah serta pengelolaan yang masih bersifat tradisional memberikan andil yang cukup besar dalam mempengaruhi Etos Kerja Masyarakat tani, dimana penanganan budidaya tanaman tidak dilakukan secara intensif dan banyak waktu luang tersisa tidak dimanfaatkan secara produktif, hal ini menyebabkan produktivitas tanaman yang diusahakan masih jauh dari rata-rata produksi tanaman di daerah lain terlebih lagi dibandingkan dengan potensi hasil tanaman yang dibudidayakan. Hal ini terkait erat dengan kurangnya informasi yang diperoleh oleh petani tentang teknik budidaya yang baik dan benar serta ramah lingkungan. Masalah ini diharapkan dapat diatasi dengan melibatkan petani secara aktif dalam kegiatan budidaya (demplot) yang dimulai dari kegiatan perencanaan, persiapan lahan, persemaian, penanaman, pemeliharaan tanaman sampai panen dan pemasaran hasil. Untuk merubah mindset petani hingga mau dan mampu dalam menerapkan dan melaksanakan serta menekuni Teknologi Budidaya Maju maka perlu dilakukan penyuluhan dan pendampingan secara intensif dengan berpegang pada Standar Operasional Prosedur (SOP) masing-masing tanaman budidaya yang dalam pelaksanaanya disesuaikan dengan status lahan dan kondisi agroklimat setempat (SOP budidaya tanaman spesifik lokasi).

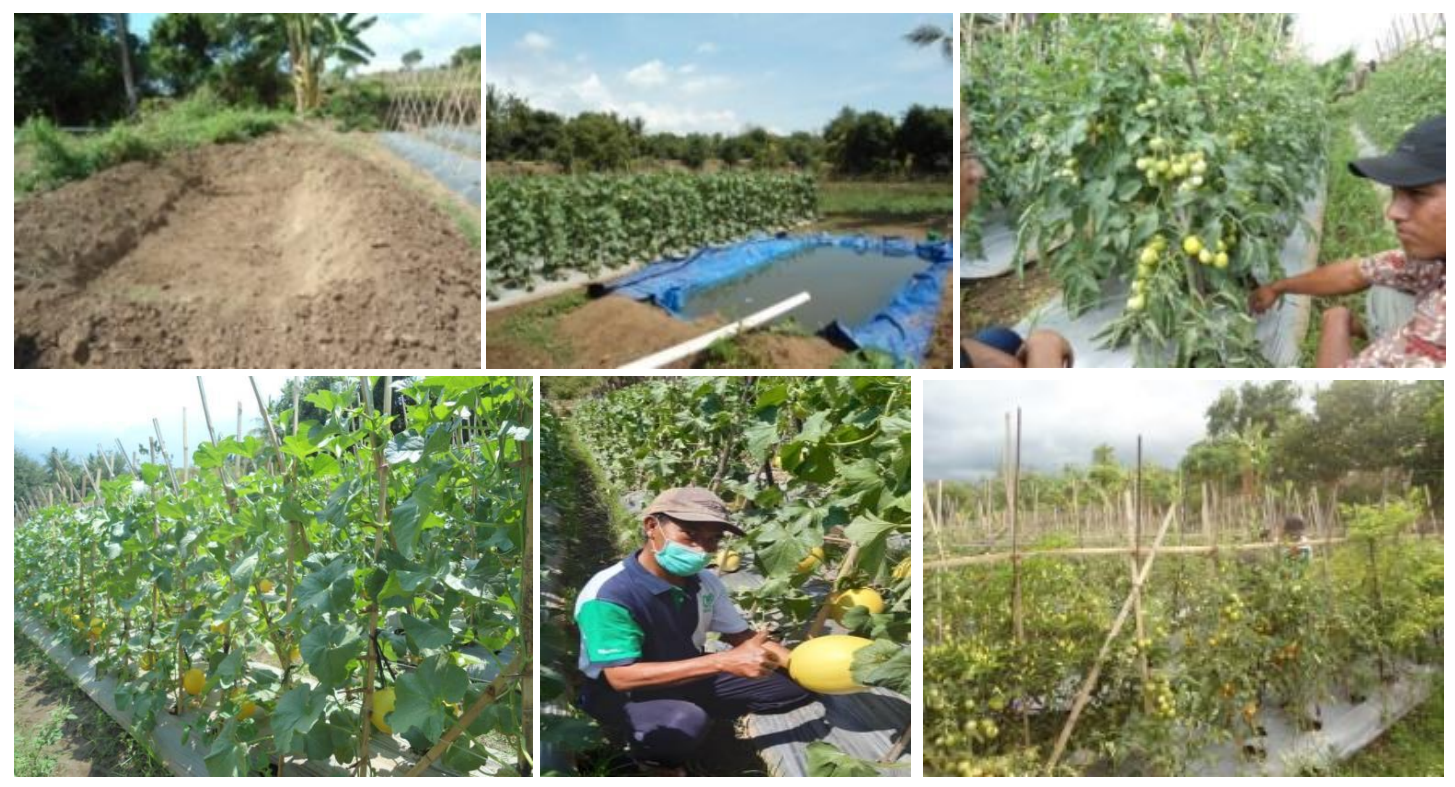

Gambar 1. Kegiatan pengabdian kepada masyarakt, searah jarum jam dari atas, salah satu fasilitas pengairan hasil gotong royong/ bak penampung air, keragaan praktek /demplot budidaya tanam Tomat timoty dan Golden melon serta keragaan pertumbuhan tanaman hasil demplot selama kegiatan pengabdian kepada masyarakat di Dusun Amor-amor, Desa Gumantar Lombok Utara.

Keterbatasan modal awal dan masalah pemasaran hasil dalam berusaha tani seringkali menjadi alasan utama masyarakat miskin (petani) tidak memanfaatkan lahan yang dimiliki secara 
optimal dengan komoditas hortikultura yang memiliki nilai ekonomi tinggi karena membutuhkan biaya usahatani yang lebih tinggi. Mereka cenderung memilih tanaman yang sudah biasa mereka tanam (jagung, kacang tanah, dan beberapa komoditas hortikultura) dengan pertimbangan biaya produksi terjangkau, teknik pengelolaannya sudah terpola secara turun temurun (masih tradisional, minim inovasi teknologi budidaya), dan mudah dipasarkan. Mahalnya biaya saprodi pertanian berakibat pada semakin terbatasnya modal usahatani sehingga dengan modal yang mereka miliki tidak mampu untuk menyokong biaya-biaya produksi yang seharusnya dikeluarkan. Keadaan tersebut menyebabkan proses produksi tidak dapat dilakukan secara intensif, pemupukan terpaksa dilakukan tidak sesuai dengan anjuran bahkan tidak melakukan pemupukan sama sekali serta pengendalian pengganggu tanaman tidak dapat dilakukan sebagaimana mestinya karena tingginya harga pestisida. Keadaan ini akan berpengaruh terhadap produktivitas tanaman yang diusahakan baik kuantitas maupun kualitas. Apabila masalah pengetahuan dan penguasaan teknologi budidaya serta etos kerja masyarakat mampu ditingkatkan, maka permasalahan modal awal usahatani dan jaminan pemasaran menjadi faktor penentu upaya peningkatan pendapatan petani dapat ditingkatkan melalui peningkatan produktivitas tanaman dan pemilihan komoditas tanaman hortikultura yang bernilai ekonomi tinggi. Pinjaman lunak dari pihak terkait menjadi solusi pemecahan masalah.

Kendala-kendala dalam berusahatani tersebut merupakan satu kesatuan yang mempengaruhi pola usahatani dan teknologi budidaya yang diterapkan petani di KLU. Oleh karena itu dalam upaya meningkatkan pendapatan / kesejahteraan masyarakat melalui diversifikasi dan intensifikasi tanaman hortikultura, maka tidak hanya aspek teknologi budidaya yang diperlukan tetapi juga faktor lain yang berkaitan dan menunjang harus ditangani secara terintegrasi, memerlukan kerja bersama lintas sektoral untuk mencapai tujuan peningkatan produktifitas usahatani dan pendapatan petani di lahan kering.

\section{Tahap Evaluasi}

Evaluasi merupakan kegiatan akhir program pengabdian kepada masyarakat yang dilakukan terhadap peran dan keterlibatan peserta, antusiasme serta serapan peserta terhadap kegiatan penyuluhan, demplot dan bimbingan yang telah dilakukan. Dalam pelaksanaan kegiatan ini tidak mendapatkan hambatan yang berarti, namun karena tingkat pendidikan dan pengalaman para peserta yang berbeda-beda, sehingga respon mereka terhadap penerimaan materi juga berbeda-beda. Untuk mengatasi masalah tersebut, penyampaian materi harus dilakukan dengan bahasa yang sederhana dan lebih banyak menggunakan bahan peraga atau lebih banyak menunjukkan contoh - contoh kasus secara langsung.

Minat dan perhatian peserta dalam mengikuti penyuluhan dan pelatihan/ demplot yang cukup tinggi merupakan faktor pendorong yang kuat dalam proses penyelenggaraan pengabdian ini. Disamping itu adanya dukungan dari aparat Desa terutama dari Kepala Desa dan Kepala Dusun, dan Ibu-ibu rumahtangga petani yang cukup kuat.

Dari hasil pengamatan selama berlangsungnya kegiatan penyuluhan, demplot dan pendampingan dapat disimpulkan beberapa hal sebagai berikut :

1. Respon peserta penyuluhan cukup besar, hal ini dapat dilihat dari keseriusan dan ketekunan seluruh peserta untuk mengikuti proses penyuluhan. Hal ini tentu dapat menjadi bekal tambahan pengetahuan mereka terkait teknologi budidaya tanaman hortikultura dan upaya pengembangannya. 
2. Materi yang disampaikan cukup relevan dengan kebutuhan peserta/kelompok sasaran, dan mudah dimengerti oleh peserta, hal ini dapat dilihat dari diskusi dan pertanyaan-pertanyaan yang diajukan oleh peserta cukup relevan dengan topik yang dibahas dan dipraktikkan.

Waktu yang disediakan dalam kegiatan penyuluhan dan pelatihan/demplot dirasa kurang terutama untuk dialog, sehingga para peserta merasa sangat perlu adanya tindak lanjut dari pertemuan tersebut. Oleh karena itu dukungan dari pemerintah setempat terutama dari aparat desa dan PPL sangat diperlukan untuk memfasilitasi penyelenggaraan tindak lanjut pertemuan dan pembinaan selanjutnya.

\section{KESIMPULAN DAN SARAN}

Bahwa kegiatan pengabdian kepada masyarakat yang dilakukan melalui program kegiatan ini merupakan kegiatan dalam rangka proses perubahan perilaku kepada masyarakat sasaran. Oleh karena itu, proses ini membutuhkan waktu yang lama untuk menilai apakah program ini sudah dapat dinilai berhasil atau tidak. Namun, dilihat dari antusiasme dan ketekunan peserta selama penyuluhan dan pelatihan/ demplot, maka kegiatan pengabdian kepada masyarakat ini dapat dinilai cukup berhasil. Budidaya tanaman hortikultura dengan penerapan teknologi yang tepat sesuai kondisi lingkungan (lahan kering) dan pengembangannya dalam upaya diversifikasi tanaman di lahan kering dapat meningkatkan produktifitas lahan kering dan peningkatan pendapatan petani per satuan luas lahan garapan. Teknologi budidaya tanaman hortikultura yang diterapkan di lahan kering, bagi masyarakat sasaran merupakan suatu hal yang dianggap sebagai inovasi teknologi baru. Sehingga melalui penyuluhan dan pelatihan/demplot yang telah dilakukan oleh tim PPM diharapkan mampu diadopsi oleh masyarakat sasaran, tentu akan membawa dampak yang sangat signifikan guna memanfaatkan potensi sumberdaya lahan kering secara berkelanjutan. Kegiatan kegiatan pengabdian kepada masyarakat dalam rangka diversifikasi tanaman di lahan kering dengan budidaya tanaman hortikultura perlu dilakukan secara berkelanjutan sehingga teknologi budidaya tanaman hortikultura yang telah disampaikan dapat terinternalisasi dalam kehidupan masyarakat

\section{Ucapan Terima Kasih}

Ucapan terima kasih kami sampaikan kepada Bapak Camat, Petugas Dinas Peternakan Kecamatan Brang Ene, Kepala Desa Mura, seluruh Anggota KTT Aik Kolong dan masyarakat Desa Mura yang telah menerima kami dengan baik.

\section{DAFTAR PUSTAKA}

Arifin, Z. 2011. Bahan Organik. http://cms.1m-bio.com/?page id=505. [20 Juli 2017]. BPS, 2019. Kabupaten Lombok Utara dalam Angka 2019. BPS Kabupaten Lombok Utara. Djuarnani N., Kristian B. S., Setiawan. 2005. Cara Cepat Membuat Kompos. Agromedia Pustaka. Higa,T., 1998. Materi Latihan Teknologi EM. Departemen Pertanian, Jakarta.

Utomo M. 2002. Pengelolaan Lahan Kering untuk Pertanian Brkelanjutan. Makalah Disampaikan pada Seminar Nasional Pengembangan Wilayah Lahan Kering Tanggal 27-28 Mei 2002 di Hotel Lombok Raya Mataram. Mataram, Provinsi NTB.

Rizal, M dan Fiana, Y. 2015.Teknologi Budidaya Tanaman Sayuran dan Toga di Perkotaan dan Pedesaan pada Kawasan Rumah Pangan Lestari dalam mendukung Ketahanan Pangan di Kalimantan Timur. Prosiding Seminar Nasional Masyarakat Biodiversitas Indonesia. Volume 1, Nomor 2, April2015. 
Rubatzky V. E., Yamaguchi M. 1997. Sayuran Dunia I Prinsip Produksi dan Gizi. Edisi Kedua. ITB. Bandung.

Sauqi, A., Bambang Dipo Kusumo, Nurrachman, Jayaputra, Sri Maryati, 2017. Kaji Tindak Pengembangan Pertanian Lahan Kering Di Kabupaten Lombok Utara. Kerjasama Fakultas Pertanian dengan Pemerintah Kabupaten Lombok Utara. Laporan Akhir.

Wibowo, R. 2000. Pertanian dan Pangan, Bunga Rampai Pemikiran menuju KetahananPangan. Sinar Harapan. Jakarta.

Zainuri, Taslim sjah, Jayaputra dan Ahmad Sauqi. 2017. Pengembangan Agrowisata Melalui Sistem Agribisnis Dan Agroindustri Terpadu Untuk Mendukung Pariwisata Dan Ekonomi Desa Gumantar Kabupaten Lombok Utara. Laporan Penelitian MP3EI Tahun ke 2. Universitas Mataram. 